\title{
確率特性を考慮したコンクリート舗装版の曲げ疲労設計曲線
}

\section{FLEXURAL FATIGUE STRENGTH EQUATION FOR CONCRETE PAVEMENT SLAB DESIGN IN CONSIDERATION OF PROBABILISTIC PROPERTIES}

\author{
小梁川 雅*·米谷裕**·福田正*** \\ By Masashi KOYANAGAWA, Hiroshi YONEYA and Tadashi FUKUDA
}

\begin{abstract}
The purposes of this study are to clarify the effect of the static flexural strength of concrete on the fatigue strength equation and to determine the design fatigue strength equation to take the reliability of concrete pavement into accout. As a result of the statistical analysis of the fatigue tests, it was found that there is almost no effect of the static strength on the fatigue strength equation for concrete pavement design. By means of the present simulation which took account of the scatters of the fatigue strength, the relationship between the failure probability of the flexural fatigue strength equation and the reliability of concrete pavement was obtained.
\end{abstract}

Keywords : concrete pavement, fatigue strength equation, reliability

\section{1. 緒 論}

著者らは, 舗装用コンクリートの曲げ疲労強度に対す る応力比（最小応力／最大応力）および粗骨材の最大寸 法の影響について実験を行い，すでに報告した 文では，さらに舗装用コンクリートの静的曲げ強度が疲 労破壊に与える影響に関する実験結果と, 本研究の総括 として, 曲げ疲労破壊の確率特性を考慮した舗装用コン クリートの曲げ疲労設計曲線に関する検討結果を報告す るものである.

わが国では, 舗装用コンクリートの設計曲げ強度は $45 \mathrm{kgf} / \mathrm{cm}^{2}$ が標準とされ，また，一部に $40 \mathrm{kgf} / \mathrm{cm}^{2} の$ 使用も認められている2). しかし現実に舗装用コンク リートとして出荷されるレディーミクストコンクリート は，文献 3）によれば圧縮強度分布で 150 ～ $300 \mathrm{kgf} / \mathrm{cm}^{2}$ の範囲にあり,これを曲げ強度に換算すると, 約 30 $60 \mathrm{kgf} / \mathrm{cm}^{2}$ の範囲となる. 前回の実験は, 現行の設計法 ${ }^{21}$ における疲労設計曲線が, 設計曲げ強度 $45 \mathrm{kgf} / \mathrm{cm}^{2}$ (配 合目標強度 $52 \mathrm{kgf} / \mathrm{cm}^{2}$ ) を対象としていることを考慮

* 正会員 工修 秋田高専助手 土木工学科 ( ₹011 秋田市飯島文京町 1-1)

** 秋田高専技官 土木工学科 (同上)

*** 正会員 工博 東北大学教授 工学部土木工学科 ( ₹980 仙台市青葉区荒巻字青葉)
して央施したものである。したがって，さらに広範囲の 静的曲げ強度のコンクリートに関して, その疲労特性を 検討する必要がある。そこで今回の実験では，配合目標 強度 $40 \mathrm{kgf} / \mathrm{cm}^{2}, 60 \mathrm{kgf} / \mathrm{cm}^{2}$ のコンクリートに関する 疲労試験を行った.

コンクリート舖装の力学的設計法においては, コンク リート舗装の疲労寿命を解析する際に, 曲げ疲労曲線は 大きな影響をもっている。したがって，コンクリート舗 装を合理的に設計するためには，コンクリートの疲労現 象の確率的特性を考慮した設計用曲げ疲労曲線を決定す る必要がある。このようなことから本研究では, 試験結 果より曲げ被労破壊の確率特性を求め, これにモンテカ ルロシミュレーション手法を適用して，コンクリートの 疲労現象のばらつきがコンクリート舗装の寿命に与える 影響の解析を行い, コンクリート舗装の設計の際に用い る曲げ疲労曲線について検討した。

\section{2. 曲げ疲労試験}

\section{（1）使用材料および配合}

本試験で用いたセメントは普通ポルトランドセメント であり，骨材は秋田県由利郡産山砂，仙北郡産砕石を用 いた．粗骨材の最大寸法は $20 \mathrm{~mm}$ とした.

試験に用いたコンクリートは，前回の実験"と同様に 
Table 1 Mix Proportion of Concrete

\begin{tabular}{|c|c|c|c|c|c|c|c|c|c|}
\hline \multirow{2}{*}{$\begin{array}{l}\text { Target } \\
\text { Strength } \\
\\
\text { kgf } / \mathrm{cm}^{2}\end{array}$} & \multirow{2}{*}{$\begin{array}{c}\text { Slump } \\
\mathrm{cm}\end{array}$} & \multirow{2}{*}{\begin{tabular}{|l|} 
Air \\
Content \\
$\%$
\end{tabular}} & \multirow{2}{*}{$\begin{array}{l}\text { Water } \\
\text { Cement } \\
\text { Ratio } \\
\%\end{array}$} & \multirow{2}{*}{$\begin{array}{l}\text { Sand } \\
\text { Per- } \\
\text { cent } \\
\%\end{array}$} & \multicolumn{5}{|c|}{ Unit Weight $\left(\mathrm{kgf} / \mathrm{m}^{3}\right)$} \\
\hline & & & & & Water & Cement & \begin{tabular}{|l|} 
Fine \\
Aggregate
\end{tabular} & \begin{tabular}{|l|} 
Coarse \\
Aggregate
\end{tabular} & \\
\hline & & $4 \pm 0.5$ & 60 & 35 & 50 & & & & \\
\hline & \pm 1 . & $4 \pm 0.5$ & 35 & 32 & 140 & 400 & & & 1.00 \\
\hline
\end{tabular}

スランプ $8.0 \mathrm{~cm}$, 空気量 $4.0 \%$ として混合し, 材令 28 日曲げ強度 $40 \mathrm{kgf} / \mathrm{cm}^{2}$ ，および $60 \mathrm{kgf} / \mathrm{cm}^{2}$ を目標とし た. Table 1 にその配合を示す。なお，混和剂として $\mathrm{AE}$ 減水剂ポゾリス No.8 IMP を使用した。

練りまぜは $50 l$ 強制練りミキサーを用いて行い, 各 バッチごとに静的強度試験用 3 本, 疲労強度試験用 6 本 の供試体を作製した。供試体の寸法は $15 \times 15 \times 53 \mathrm{~cm}$ で, 載荷試験まで水温 $20^{\circ} \mathrm{C}$ の恒温水槽で養生を行った. 疲労試験は供試体強度の安定を考慮して，材令 2 か月以 降に開始した。

\section{（2）試験方法}

載荷方法は静的強度試験, 疲労強度試験ともにスパン $45 \mathrm{~cm}$ の 3 等分点載荷とした。試験装置は前回の実験と 同機種であるサーボパルサー（島津 EHF-U 20）を用 いた。

各バッチにおける静的曲げ強度を Table 2 に示す。配 合目標強度（以下目標強度と略す） $40 \mathrm{kgf} / \mathrm{cm}^{2}$ の場合 の全供試体の平均曲げ強度および標準偏差は, それぞれ $43.9 \mathrm{kgf} / \mathrm{cm}^{2}, 2.68 \mathrm{kgf} / \mathrm{cm}^{2}$, また目標強度 $60 \mathrm{kgf} / \mathrm{cm}^{2}$ の場合では $63.1 \mathrm{kgf} / \mathrm{cm}^{2}, 4.25 \mathrm{kgf} / \mathrm{cm}^{2}$ であった。

著者らの別の実験 ${ }^{4)}$ にれば，コンクリートの曲げ強 度は, 試験時における供試体内の水分変化の影響を敏感 に受ける。そこで, 疲労試験期間における供試体内の水 分状態を安定させるために，前回の実験と同様に供試体 の周囲にグリースを塗布し, さらにビニール樹脂薄膜で 被覆して疲労試験を行った。

疲労試験の応力波形は, 周波数 $5 \mathrm{~Hz}$ の正弦曲線変化

Table 2 Results of Flexural Strength Test.

\begin{tabular}{|c|c|c|c|c|c|}
\hline $\begin{array}{l}\text { Target } \\
\text { Strength } \\
\text { kgf/cm } \\
\end{array}$ & $\begin{array}{c}\text { Batch } \\
\text { No. }\end{array}$ & Flexur & al Str & ength & $\begin{array}{c}\text { Mean } \\
\mathrm{kgf} / \mathrm{cm}^{2} \\
\end{array}$ \\
\hline \multirow{8}{*}{40} & 1 & 44.8 & 46.9 & 45.0 & 46 \\
\hline & 2 & 42.9 & 45.5 & 49.0 & 46 \\
\hline & 3 & 45.8 & 37.4 & 45.4 & 43 \\
\hline & 4 & 44.1 & 43.5 & 39.8 & 42 \\
\hline & 5 & 45.5 & 45.1 & 43.9 & 45 \\
\hline & 6 & 40.5 & 41.7 & 41.0 & 41 \\
\hline & 7 & 46.1 & 44.9 & 44.1 & 45 \\
\hline & 8 & 39.6 & 47.5 & 43.6 & 44 \\
\hline \multirow{8}{*}{60} & 1 & 70.0 & 63.6 & 69.0 & 68 \\
\hline & 2 & 59.4 & 65.3 & 58.8 & 61 \\
\hline & 3 & 66.6 & 64.0 & 63.1 & 65 \\
\hline & 4 & 71.2 & 69.2 & 65.1 & 69 \\
\hline & 5 & 65.8 & 61.2 & 62.3 & 63 \\
\hline & 6 & 59.4 & 58.7 & 55.3 & 58 \\
\hline & 7 & 64.7 & 63.1 & 65.2 & 64 \\
\hline & 8 & 57.5 & 58.4 & 57.8 & 58 \\
\hline
\end{tabular}

とした.この繰り返し応力波形の最大応力 $\left(\sigma_{\max }\right)$ と静的 強度 $\left(\sigma_{b}\right)$ の比を応力レベル $\left(S=\sigma_{\max } / \sigma_{b}\right)$ と定義する. 本研究の疲労試験における応力レベル $S$ は, 0.90 , $0.85 ， 0.80,0.70$ の 4 段階である. 各応力レベルにおけ る供試体数は Table 3 に示すとおりである.

繰り返し応力波形の最小応力は $2.5 \mathrm{kgf} / \mathrm{cm}^{2}$ とした. また，本試験では前回の研究成果 ${ }^{1}$ より，繰り返し回数 200 万回で供試体が破壊しない場合，試験を途中打ち切 りとした.

\section{（3）試験 結果}

Table 4 は, 目標強度 $40 \mathrm{kgf} / \mathrm{cm}^{2}$ の場合および 60 $\mathrm{kgf} / \mathrm{cm}^{2}$ の場合の疲労試験結果である. 表中の $\rightarrow$ 表示 は，その繰り返し回数で供試体が破壊せずに，途中打ち 切りとなった供試体を示している.

Table 3 Number of Specimens.

\begin{tabular}{|c|c||c|}
\hline $\begin{array}{c}\text { Target } \\
\text { Strength } \\
\text { kgf/cm }\end{array}$ & $\begin{array}{l}\text { Stress } \\
\text { Level }\end{array}$ & $\begin{array}{l}\text { Number of } \\
\text { Specimens }\end{array}$ \\
\hline \multirow{3}{*}{40} & 0.90 & 12 \\
\cline { 2 - 3 } & 0.85 & 12 \\
\cline { 2 - 3 } & 0.80 & 12 \\
\cline { 2 - 3 } & 0.70 & 12 \\
\hline \multirow{3}{*}{60} & 0.90 & 12 \\
\cline { 2 - 3 } & 0.85 & 12 \\
\cline { 2 - 3 } & 0.80 & 12 \\
\cline { 2 - 3 } & 0.70 & 12 \\
\hline
\end{tabular}

Table 4 Results of Fatigue Test.

\begin{tabular}{|c|c|c|c|c|}
\hline \multirow{2}{*}{\begin{tabular}{|l|} 
Target \\
Strength \\
kgf $/ \mathrm{cm}^{2}$ \\
\end{tabular}} & \multicolumn{4}{|c|}{ Stress Level } \\
\hline & 0.90 & 0.85 & 0.80 & 0.70 \\
\hline \multirow{12}{*}{40} & 1947 & 979 & 722515 & 773439 \\
\hline & 663 & 1665 & 6671 & 1423374 \\
\hline & 22886 & 4837 & 10767 & 847262 \\
\hline & 6359 & 1372 & 740 & 1714121 \\
\hline & 17219 & 1759 . & 4204 & $2000000 \rightarrow$ \\
\hline & 1805 & $4193^{\prime}$ & 10224 & 109410 \\
\hline & 4297 & 3257 & 23439 & $2000000 \rightarrow$ \\
\hline & 471 & 1647 & 38699 & 1100128 \\
\hline & 4801 & 6666 & 44809 & 897491 \\
\hline & 1307 & 45970 & 32077 & 67943 \\
\hline & 49020 & 989 & 50999 & 1245830 \\
\hline & 10423 & 5455 & 25838 & $2000000 \rightarrow$ \\
\hline \multirow{12}{*}{60} & 670 & 3997 & 5729 & $2000000 \rightarrow$ \\
\hline & 1957 & 1093 & 76584 & $2000000 \rightarrow$ \\
\hline & 733 & 652 & 49526 & 937874 \\
\hline & 14197 & 1966 & 160099 & 1532671 \\
\hline & 3245 & 2511 & 66784 & $2000000 \rightarrow$ \\
\hline & 952 & 8897 & 65603 & 452906 \\
\hline & 14214 & 1346 & 3124 & $2000000 \rightarrow$ \\
\hline & 22269 & 13668 & 75169 & 622111 \\
\hline & 150 & 4897 & 10473 & $2000000 \rightarrow$ \\
\hline & 319 & 11345 & 36637 & $2000000 \rightarrow$ \\
\hline & $\frac{1081}{2010}$ & 34699 & $2000000 \rightarrow$ & $2000000 \rightarrow$ \\
\hline & 3849 & 4367 & 20000 & \\
\hline
\end{tabular}




\section{3. 曲げ疲労に対する静的強度の影響}

2 種類の目標強度に関する疲労試験結果に, さらに前 回に実施した目標強度 $52 \mathrm{kgf} / \mathrm{cm}^{2}$ の場合の試験結果を 補足し, 静的強度が異なるコンクリートの疲労破壊特性 について応力レベルごとに検討することにした．

Table 4 からわかるように各応力レベルにおいて, 疲 労試験結果はかなりのばらつきを示している.したがっ て静的強度の影響を検討する場合には，このばらつきを 考慮しなければならない。

本研究では各応力レベルにおいて, それぞれの目標強 度の供試体による疲労試験結果を 1 つの標本集団と考 え, それぞれの標本集団が属する母集団の平均值および 分散に関して統計的仮説検定を行った. 平均値の検定に おいては「2つの分布の平均值は等しい」ことを, 分散 の検定においては「2つの分布の分散は等しい」ことを 仮説として設定した. そして，平均値の仮説検定には $t$ 検定を，分散の仮説検定には $F$ 検定を用いた。

検定を行った応力レベルは $S=0.90,0.80$ の 2 段階 であり，それぞれの応力レベルに関し，目標強度 40 $\mathrm{kgf} / \mathrm{cm}^{2}$ と $60 \mathrm{kgf} / \mathrm{cm}^{2}, \quad 60 \mathrm{kgf} / \mathrm{cm}^{2}$ と $52 \mathrm{kgf} / \mathrm{cm}^{2}, \quad 40$ $\mathrm{kgf} / \mathrm{cm}^{2}$ と $52 \mathrm{kgf} / \mathrm{cm}^{2}$ の場合の疲労試験結果について 個々に検討した。 その結果，いずれの場合においても平 均值，分散双方に関して有意水準 $5 \%$ で仮説が採択さ れ, 応力レベルが高い領域においては, 静的強度が異なっ ても応力レベルと曲げ疲労破壊に至る繰り返し数の関係 は同一であることが確認された.

一方, 応力レベル $S=0.70$ において, 途中打ち切り 供試体の割合を比較すると, 目標強度 $40 \mathrm{kgf} / \mathrm{cm}^{2}$ の場 合には，12 本中 3 本 $(25 \%)$ であるのに対して，52 $\mathrm{kgf} / \mathrm{cm}^{2}$ の場合には 18 本中 11 本 $(61 \%), 60 \mathrm{kgf} / \mathrm{cm}^{2}$ の場合には 12 本中 8 本 $(67 \%)$ と, 目標強度の増加に 従って途中打ち切り供試体数の割合が増加している. す なわち静的強度の増加に伴って疲労強度が大きくなる傾 向があることがわかる。

\section{4. 曲げ疲労の確率特性}

上述のように曲げ疲労寿命に対する静的強度の影響 は, 応力レベル $S=0.70$ のデータにおいて若干認めら れるが, 特にコンクリート舗装の設計において疲労解析 に大きい影響を与える $S=0.80$ 以上の領域では, 静的 強度の影響は無視できる. そこで, 目標強度 $40 \mathrm{kgf} / \mathrm{cm}^{2}$, $52 \mathrm{kgf} / \mathrm{cm}^{2}, \quad 60 \mathrm{kgf} / \mathrm{cm}^{2}$ のすべてのデータを用いて, 新 たに曲げ疲労曲線を作成した。

疲労試験においては, 各応力レベルにおいて疲労破壊 は広範なばらつきを示す (Table 4 ). このばらつきは 疲労現象に固有の性質であると考えられるので, 疲労曲
線の作成にあたつては，統計的検討が必要である。すな わち, 各応力レベルごとの疲労試験結果を 1 つの母集団 と考え, その確率分布関数を決定しなければならない.

各母集団に属する供試体の破壊確率は順序統計量の方 法によれば，次式によって与えられる.

$$
P_{f i}=\frac{i}{n+1}
$$

ここで, $P_{f i}$ : 各応力レベルの疲労寿命を小さい順に並べ た場合の $i$ 番目の供試体の破壊確率 $n$ : 各応力レベルの試験供試体個数 また, 途中打ち切りとなった供試体を含む場合には, 破 壊確率は次式によって与えられる5!.

Table 5 Probability of Failure of Specimens.

\begin{tabular}{|c|c|c|c|c|c|c|c|c|}
\hline \multirow[b]{2}{*}{ i } & \multicolumn{2}{|c|}{$\mathrm{S}=0.90$} & \multicolumn{2}{|c|}{$\mathrm{S}=0.85$} & \multicolumn{2}{|c|}{$\mathrm{S}=0.80$} & \multicolumn{2}{|c|}{$\mathrm{S}=0.70$} \\
\hline & C.F. & $P_{f}$ & C.F. & $P_{f}$ & C.F. & $P_{f}$ & C.F. & $P_{f}$ \\
\hline & 150 & 0.021 & 315 & 0.027 & 740 & 0.020 & $2.3 \mathrm{E} 4$ & 0.022 \\
\hline 2 & 264 & 0.043 & 451 & 0.054 & 1547 & 0.039 & $6.8 \mathrm{E} 4$ & 0.046 \\
\hline 3 & 319 & 0.064 & 652 & 0.081 & 3124 & 0.059 & $1.1 \mathrm{E} 5$ & \begin{tabular}{|l|}
0.068 \\
\end{tabular} \\
\hline 4 & 471 & 0.085 & 811 & 0.108 & 3685 & 0.078 & $1.1 \mathrm{E} 5$ & 0.090 \\
\hline 5 & 498 & 0.106 & 979 & 0.135 & 4204 & 0.098 & $2.1 \mathrm{E5}$ & 0.114 \\
\hline 6 & 591 & 0.128 & 989 & 0.162 & 5729 & 0.118 & $3.4 \mathrm{E5}$ & \begin{tabular}{|l|}
0.136 \\
\end{tabular} \\
\hline 7 & 663 & 0.149 & 1093 & 0.189 & 5980 & 0.137 & $4.5 \mathrm{E} 5$ & 0.159 \\
\hline 8 & 670 & 0.170 & 1274 & 0.216 & 6671 & 0.157 & $5.9 \mathrm{E} 5$ & 0.182 \\
\hline 9 & 733 & 0.192 & 1346 & 0.243 & 7582 & 0.177 & $6.2 \mathrm{E5}$ & 0.205 \\
\hline 10 & 952 & 0.213 & 1372 & 0.270 & 9525 & 0.196 & $7.7 \mathrm{E} 5$ & 0.227 \\
\hline 11 & 952 & 0.234 & 1647 & 0.297 & $1.0 \mathrm{E} 4$ & 0.216 & $8.5 \mathrm{E} 5$ & 0.250 \\
\hline 12 & 1081 & 0.255 & 1665 & 0.324 & $1.0 \mathrm{E} 4$ & 0.235 & $9.0 \mathrm{E} 5$ & 0.273 \\
\hline 13 & 1307 & 0.277 & 1759 & 0.351 & $1.0 \mathrm{E} 4$ & 0.254 & $9.4 \mathrm{ES}$ & 0.296 \\
\hline 14 & 1444 & 0.298 & 1966 & 0.378 & $1.1 \mathrm{E4}$ & 0.275 & $1.1 \mathrm{E6}$ & 0.318 \\
\hline 15 & 1767 & 0.319 & 2511 & 0.405 & $1.6 \mathrm{E} 4$ & 0.294 & $1.2 \mathrm{E} 6$ & 0.341 \\
\hline 16 & 1805 & 0.340 & 3060 & 0.432 & $2.3 \mathrm{E} 4$ & 0.313 & $1.4 \mathrm{E} 6$ & \begin{tabular}{|l|}
0.364 \\
\end{tabular} \\
\hline 17 & 1947 & 0.362 & 3257 & 0.460 & $2.3 \mathrm{E} 4$ & 0.333 & $1.5 \mathrm{E} 6$ & 0.386 \\
\hline 18 & 1957 & 0.383 & 3640 & 0.487 & $2.6 \mathrm{E} 4$ & 0.353 & $1.7 \mathrm{E} 6$ & 0.409 \\
\hline 19 & 2283 & 0.404 & 3997 & 0.514 & $3.2 \mathrm{E} 4$ & 0.373 & $2.1 \mathrm{E} 6$ & 0.432 \\
\hline 20 & 2834 & 0.426 & 4193 & 0.541 & $3.2 \mathrm{E} 4$ & 0.392 & $2.6 \mathrm{E} 6$ & 0.455 \\
\hline 21 & 2845 & 0.447 & 4367 & 0.568 & $3.2 \mathrm{E} 4$ & 0.412 & $2.0 \mathrm{E} 6 \rightarrow$ & \\
\hline 22 & 3245 & 0.468 & 4837 & 0.595 & $3.7 \mathrm{E} 4$ & 0.431 & $2.0 \mathrm{E} 6 \rightarrow$ & \\
\hline 23 & 3849 & 0.489 & 4897 & 0.622 & $3.9 \mathrm{E} 4$ & 0.451 & $2.0 \mathrm{E} 6 \rightarrow$ & \\
\hline 24 & 3907 & \begin{tabular}{|l|}
0.511 \\
\end{tabular} & 5455 & 0.649 & $4.2 \mathrm{E} 4$ & 0.471 & $2.0 \mathrm{E} 6 \rightarrow$ & \\
\hline 25 & 4147 & 0.532 & 6232 & 0.676 & $4.5 \mathrm{E} 4$ & 0.490 & $2.0 \mathrm{E} 6 \rightarrow$ & \\
\hline 26 & 4297 & 0.553 & 6666 & 0.703 & $4.6 \mathrm{E} 4$ & 0.510 & $2.0 \mathrm{E} 6 \rightarrow$ & \\
\hline 27 & 4464 & 0.575 & 8897 & 0.730 & $5.1 \mathrm{E} 4$ & 0.529 & $2.0 \mathrm{E} 6 \rightarrow$ & \\
\hline 28 & 4506 & \begin{tabular}{|l|}
0.596 \\
\end{tabular} & $1.1 \mathrm{E} 4$ & \begin{tabular}{|l|}
0.757 \\
\end{tabular} & $5.1 \mathrm{E} 4$ & 0.549 & $2.0 \mathrm{E} 6 \rightarrow$ & \\
\hline 29 & 4801 & 0.617 & $1.1 \mathrm{E} 4$ & 0.784 & $6.6 \mathrm{E} 4$ & 0.569 & $2.0 \mathrm{E} 6 \rightarrow$ & \\
\hline \begin{tabular}{|l|}
30 \\
\end{tabular} & 5714 & 0.638 & $1.4 \mathrm{E} 4$ & 0.811 & $6.7 \mathrm{E} 4$ & 0.588 & $2.0 \mathrm{E} 6 \rightarrow$ & \\
\hline \begin{tabular}{|c||}
31 \\
\end{tabular} & 6359 & 0.660 & $1.8 \mathrm{E} 4$ & 0.838 & $7.5 \mathrm{E} 4$ & 0.608 & $2.0 \mathrm{E} 6 \rightarrow$ & \\
\hline 32 & 8900 & \begin{tabular}{|l|}
0.681 \\
\end{tabular} & $3.4 \mathrm{E} 4$ & 0.865 & $7.7 \mathrm{E} 4$ & 0.628 & $2.0 \mathrm{E} 6 \rightarrow$ & \\
\hline 33 & $1.0 \mathrm{E} 4$ & \begin{tabular}{|l|}
0.702 \\
\end{tabular} & $3.5 \mathrm{E} 4$ & 0.895 & $1.6 \mathrm{E} 5$ & 0.647 & $2.0 \mathrm{E} 6 \rightarrow$ & \\
\hline 34 & $1.4 \mathrm{E} 4$ & 0.723 & $4.6 \mathrm{E} 4$ & 0.919 & $2.4 \mathrm{E} 5$ & 0.667 & $2.0 \mathrm{E} 6 \rightarrow$ & \\
\hline 35 & $1.4 \mathrm{E} 4$ & 0.745 & $6.9 \mathrm{E5}$ & 0.946 & $4.2 \mathrm{E5}$ & 0.686 & $2.0 \mathrm{E} 6 \rightarrow$ & \\
\hline 36 & $1.4 \mathrm{E} 4$ & 0.766 & $9.6 \mathrm{E} 5$ & 0.973 & $7.2 \mathrm{E5}$ & 0.706 & $2.0 \mathrm{E} 6 \rightarrow$ & \\
\hline \begin{tabular}{|l||}
37 \\
\end{tabular} & $1.7 \mathrm{E} 4$ & 0.787 & & & $7.4 \mathrm{ES}$ & 0.726 & $2.0 \mathrm{E} 6 \rightarrow$ & \\
\hline 38 & $2.1 \mathrm{E} 4$ & 0.809 & & & $1.2 \mathrm{E} 6$ & 0.745 & $5.0 \mathrm{E} 6 \rightarrow$ & \\
\hline 39 & $2.2 \mathrm{E} 4$ & 0.830 & & & $1.4 \mathrm{E} 6$ & 0.765 & $5.0 \mathrm{E} 6 \rightarrow$ & \\
\hline 40 & $2.3 \mathrm{E}$ & 0.851 & & & $1.5 \mathrm{E} 6$ & 0.784 & $5.0 \mathrm{E} 6 \rightarrow$ & \\
\hline \begin{tabular}{|l||}
41 \\
\end{tabular} & $2.3 \mathrm{E} 4$ & 0.872 & & & 2.1E6 & 0.804 & $5.0 \mathrm{E} 6 \rightarrow$ & \\
\hline \begin{tabular}{|l|}
42 \\
\end{tabular} & $2.5 \mathrm{E} 4$ & 0.894 & & & $3.1 \mathrm{E} 6$ & 0.824 & $5.0 \mathrm{E} 6 \rightarrow$ & \\
\hline 43 & $2.7 \mathrm{E} 4$ & 0.915 & & & $2.0 \mathrm{E} 6 \rightarrow$ & & & \\
\hline 44 & $3.0 \mathrm{E} 4$ & 0.936 & & & $2.0 \mathrm{E} 6 \rightarrow$ & & & \\
\hline \begin{tabular}{|l|l|}
45 \\
\end{tabular} & $4.9 \mathrm{E} 4$ & 0.957 & & & $2.0 \mathrm{E} 6 \rightarrow$ & & & \\
\hline \begin{tabular}{|l||}
46 \\
\end{tabular} & $3.0 \mathrm{E} 5$ & 0.979 & & & $3.0 \mathrm{E} 6 \rightarrow$ & & & \\
\hline 47 & & & & & $3.0 \mathrm{E} 6 \rightarrow$ & & & \\
\hline 48 & & & & & $5.0 \mathrm{E} 6 \rightarrow$ & & & \\
\hline 49 & & & & & $5.0 \mathrm{E} 6 \rightarrow$ & & & \\
\hline
\end{tabular}

S:Stress Level C.F.:Cycles to Failure $P_{f}:$ Probability of Pailure 


$$
P_{f i}=\frac{i}{n+2}
$$

なお式（2）における $n$ には，途中打ち切り供試体の 個数も含まれる.

式（1)，（2）を用いて，各応力レベルごとに破壊確 率を計算すると Table 5 のようになる。またこれらの結 果を対数正規確率紙上に示すと Fig. 1 のようになり，各 応力レベルごとのデータはほぼ一直線上に並ぶ。した がって，各応力レベルにおけるデータは，それぞれ対数 正規分布の母集団に属することが示された。なおこのこ とは, 有意水準 $5 \%$ のコルモゴロフースミルノフ検定に よって確認された。

Table 6 は, 各応力レベルにおける対数正規分布のパ

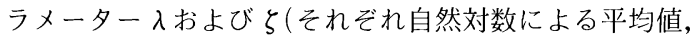
標準偏差值）を示したものである。これにより，ある破 壊確率 $P_{f}$ に対応する疲労破壊繰り返し数 $N$ を求める ことができる。なお Table 6 からわかるように，デー夕 のばらつきは応力レベルが低くなると大きくなる傾向が みられるが， $S=0.80$ で最大となった。

以上により各応力レベルにおいて，曲げ疲労の確率分 布関数が明らかとなったので，ある破壊確率 $P_{f}$ に対応 する応力レベル $S$ と疲労破壊繰り返し数 $N$ の関係式で ある疲労曲線を決定することができる．Fig. 2 に破壊確 率 $P_{f}=10 \sim 90 \%$ の疲労曲線を示す．一般に，疲労曲線 は式 (3) の形式で表現され，係数 $a$ および $b$ は実験 から定まる係数である。

$S=b-a \log (N)$

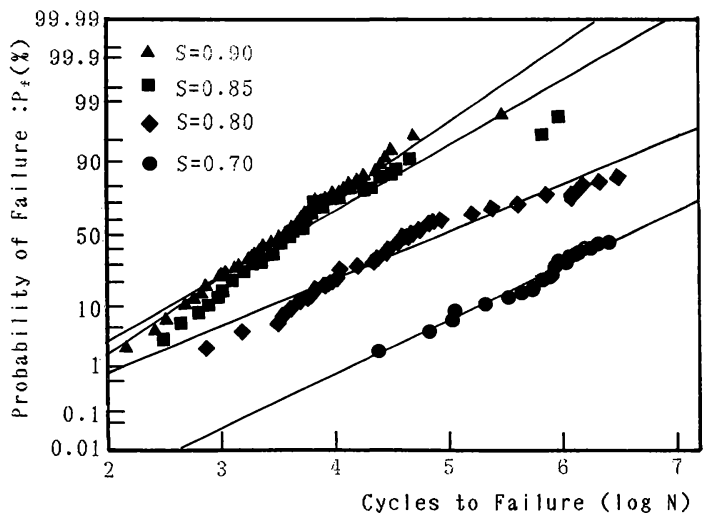

Fig. $1 P_{f^{-}} N$ Diagram for Stress Level.

Table 6 Parameters of Log-Normal Distribution for Fatigue Strength.

\begin{tabular}{|c||c||c|}
\hline$S$ & $\lambda$ & $\zeta$ \\
\hline 0.90 & 8.231 & 1.6972 \\
\hline 0.85 & 8.431 & 1.9955 \\
\hline 0.80 & 11.401 & 2.7894 \\
\hline 0.70 & 15.137 & 2.3832 \\
\hline
\end{tabular}

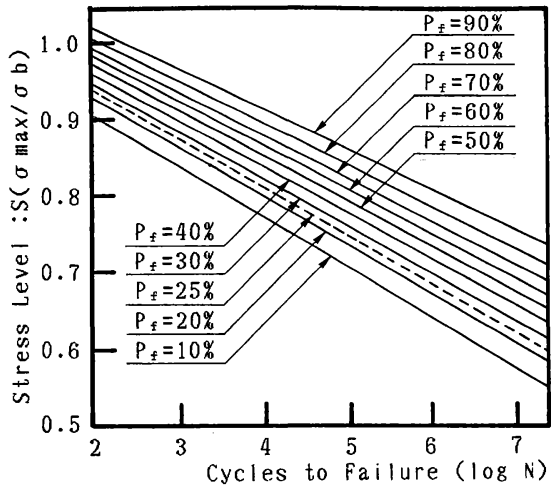

Fig. $2 S-N$ Diagram for $P_{f}$

Table 7 Coefficients of Fatigue Strength Equation.

\begin{tabular}{|c||c|c|}
\hline $\mathrm{P}_{f}(\%)$ & $\mathrm{a}$ & $\mathrm{b}$ \\
\hline 10 & 1.037 & 0.065 \\
\hline 20 & 1.058 & 0.063 \\
\hline 25 & 1.066 & 0.063 \\
\hline 30 & 1.072 & 0.062 \\
\hline 40 & 1.082 & 0.061 \\
\hline 50 & 1.091 & 0.059 \\
\hline
\end{tabular}

ここで, $S:$ 応力レベル

$N$ ：破壊に至る繰り返し数

Fig. 2 に示した破壊確率ごとの疲労曲線のうち，破壊確 率 $P_{f}=10 \sim 50 \%$ の各曲線の $a$ および $b$ は, Table 7 に 示すようになった。ここで $N \geqq 100$ である.

なお，著者らは前回の報告1)で疲労曲線を示している が，これと今回の疲労曲線を破壊確率 $P_{f}=50 \%$ の場合 に関して比較する之，同じ繰り返し回数 $N$ に対する応 カレベル $S$ の差異は約 0.01〜0.02であって, 両者に実 質的な差異はない。

\section{5. 曲げ疲労曲線の破壊確率とコンクリート版 の疲労値との関係}

コンクリート舖装の力学的設計法においては，使用す る設計曲げ疲労曲線によって，設計結果を安全側に与え ている場合が多い。たとえば舗装要綱付録の設計法にお ける設計曲げ疲労曲線は, 疲労破壊の実験值の包絡線, すなわち破壊確率ゼロ％の曲線が選ばれている ${ }^{2,6)}$. し かしながら，この曲げ疲労曲線の破壊確率とコンクリー 卜版の疲労值との関係は明確にされておらず，このため 設計システムとしての信頼性は定量的には不明確のまま 取り扱われている，そこで本研究では，曲げ疲労曲線の 破壊確率とコンクリート版の疲労値との関係を，モンテ カルロシミュレーションによって検討した。

Fig. 3 に本研究で行ったシミュレーションのフロー チャートを示す. 本シミュレーションの基礎となるコン クリート版の疲労解析は, 舗装要綱付録の設計法を一部 


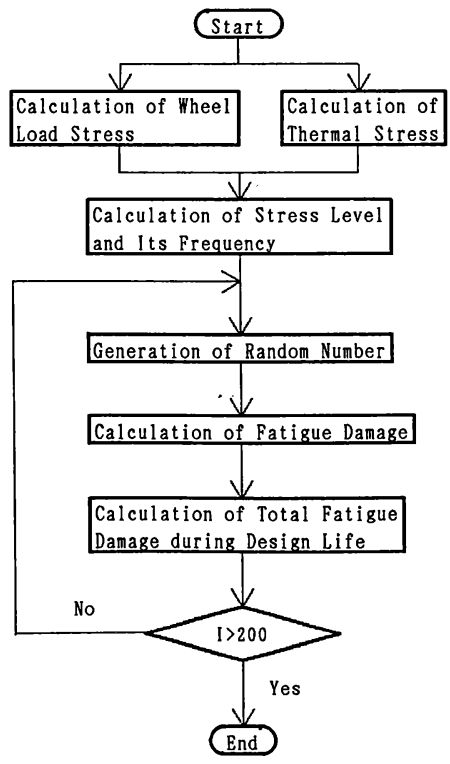

Fig. 3 Flow Chart of Simulation.

修正して用いた。なおこの修正設計法については，著者 らによる既往の研究》において実舗装の供用成績との適 合性を確かめている. 主な修正点は次のとおりである.

a) コンクリートの疲労特性は, 本研究の成果を用い る.

b）コンクリート版の横目地縁部を応力解析の基準と する.

c) 車輪の走行位置と走行頻度は著者らの調査結果 ${ }^{81}$ である Table 8 を用いる.

d）交通輪荷重分布は，建設省による実測結果である Table $9^{9 !}$ を用いる.

シミュレーションではまず輪荷重応力と温度応力との 合成応力を求め, これょり応力レベルとその作用度数を 計算する. 次にこの度数に相応した個数の乱数を発生さ

Table 8 Transverse Distribution of Wheel Load Placement and Its Relative Frequency.

\begin{tabular}{|l||l|l|r|r|}
\hline $\begin{array}{l}\text { Placement of (cm) } \\
\text { Wheel Load* }\end{array}$ & 15 & 45 & 75 & $\begin{array}{c}\text { vver } \\
75\end{array}$ \\
\hline $\begin{array}{l}\text { Relative (\%) } \\
\text { Frequency }\end{array}$ & 51 & 43 & 5 & 1 \\
\hline
\end{tabular}

*Distance from the Center of the Most Frequent Passing Position of Wheel Loads
せる.この乱数は, 乗算合同法による一様乱数に, 中心 極限定理を応用して得られたもので，Table 6 に示した

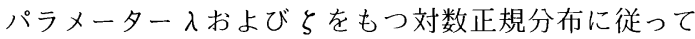
発生させた．それぞれの乱数に対して疲労破壊に至るま での許容繰り返し数が得られ，これに Minerによる累 積疲労損傷仮説を適用することによってコンクリート版 の疲労值が計算される。このシミュレーションは 1 年間 の交通量として, Table 9 の輪荷重載荷数を 365 倍して 実行した. そして設計寿命 20 年の疲労值は, このシミュ レーションによって得られた疲労值を 20 倍して求めた。 さらに,得られた疲労值より供用寿命を計算した.シミュ レーションの試行回数は, 著者らによるこの種のシミュ レーションに関する研究101を参考に 200 回とした。

シミュレーションの対象としたコンクリート舗装およ び交通条件は次のとおりである.

\begin{tabular}{ll} 
コンクリートの曲げ強度 & $\sigma_{b}=45 \mathrm{kgf} / \mathrm{cm}^{2}$ \\
コンクリートの弾性係数 & $E=350000 \mathrm{kgf} / \mathrm{cm}^{2}$ \\
コンクリートのポアソン比 & $\mu=0.25$ \\
コンクリートの温度膨張係数 & $\alpha=0.00001 /{ }^{\circ} \mathrm{C}$ \\
路盤支持力係数 & $K_{75}=8 \mathrm{kgf} / \mathrm{cm}^{3}$ \\
コンクリート版厚 & $H=25 \mathrm{~cm}$ \\
交通量区分 & $(2)$ \\
\hline
\end{tabular}

Fig. 4 は, シミュレーションの結果得られた供用寿命 のばらつきを示すヒストグラムである. 次に，このヒス トグラムを図中に示されるようなべー夕分布関数によっ て確率密度曲線に変換した。ここでこの曲線の供用寿命

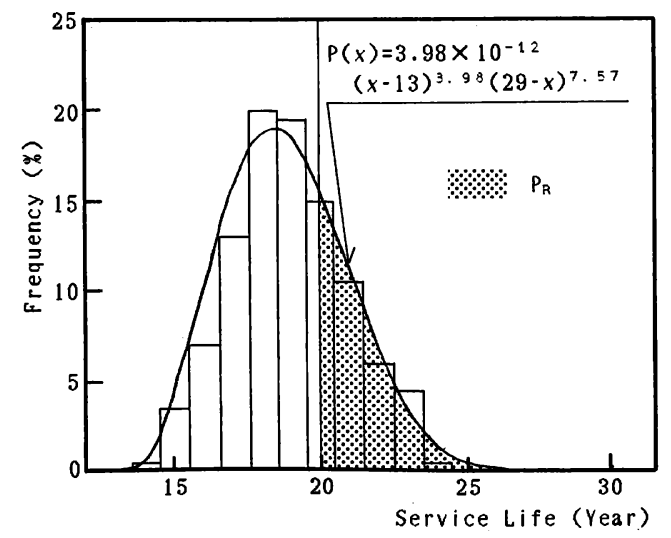

Fig. 4 Service Life Distribution.

Table 9 Distribution of Wheel Loads.

\begin{tabular}{|c|c|c|c|c|c|c|c|c|c|c|c|c|c|}
\hline \multirow{3}{*}{$\begin{array}{l}\text { Traffic } \\
\text { Volume } \\
\text { Level } \\
\end{array}$} & \multirow{3}{*}{ M.N.T.V. } & \multirow{3}{*}{ M.N.C.V. } & \multicolumn{11}{|c|}{ Number of Wheel Loads } \\
\hline & & & $0-1$ & $1-2$ & $2-3$ & $3-4$ & 7) $4-5$ & $5-6$ & $6-7$ & $7-8$ & \begin{tabular}{|l|l|}
$8-9$ & $9-10$ \\
\end{tabular} & $10-12$ & $12-14$ \\
\hline & & & $t$ & & $t$ & $\mathrm{t}$ & $\mathrm{t}$ & $t$ & $\mathrm{t}$ & $\mathrm{t}$ & \begin{tabular}{l|l}
$t$ & $t$ \\
\end{tabular} & $t$ & $t$ \\
\hline $\mathrm{B}$ & 4986 & 749 & 8371 & 810 & 420 & 229 & $\overline{119}$ & 79 & 45 & 27 & 6.7 & 4.3 & 0.70 \\
\hline $\bar{C}$ & 8930 & 1889 & 13934 & 1855 & 1210 & 620 & 335 & 208 & 118 & 59 & \begin{tabular}{l|l|}
30 & 13.0 \\
\end{tabular} & 8.5 & 1.81 \\
\hline $\bar{D}$ & 12727 & 4696 & 16610 & 3611 & 3091 & 1978 & 1005 & 623 & 378 & 176 & \begin{tabular}{l|l|}
86 & 36.0 \\
\end{tabular} & 19.0 & 2.04 \\
\hline
\end{tabular}


$\geqq 20$ 年の領域を積分した面積は，コンクリートの疲労 強度のばらつきに起因するコンクリート舗装の破壊に対 する信頼性確率であるので，これを疲労に関する信頼性 確率 $P_{R}$ と定義すれば，この例では $P_{R}=29.4 \%$ である.

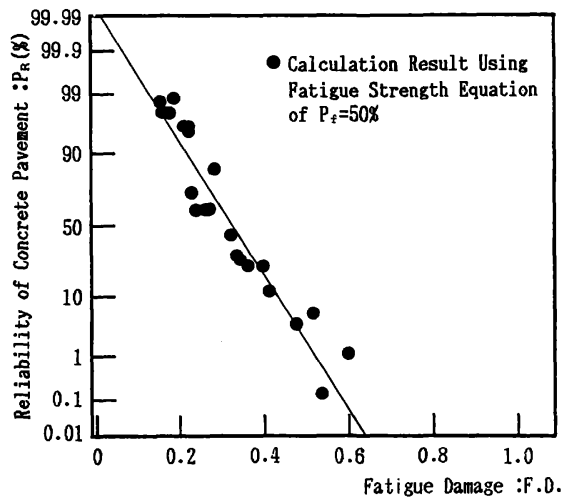

Fig. 5 Relationship between Fatigue Damage and Reliability in Case of $H=25 \mathrm{~cm}, \mathrm{D}$-traffic.

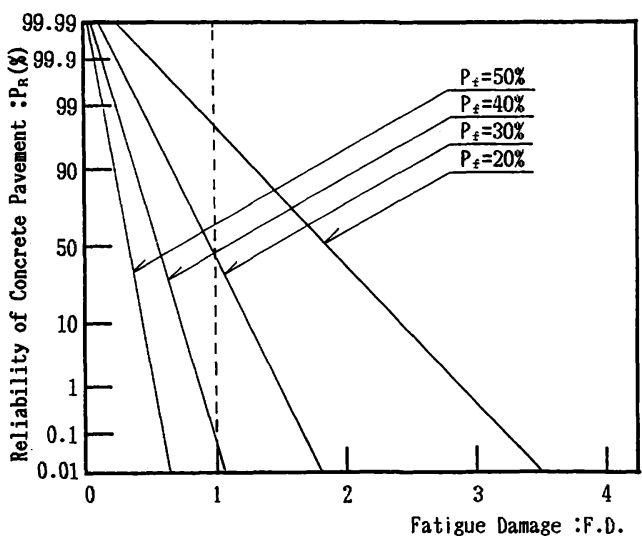

Fig. $6 P_{R^{-}} P_{f^{-}} F D$ Relationship in Case of $H=25 \mathrm{~cm}$, D-traffic.
一方，これに対して，このコンクリート舗装について， ある破壊確率 $P_{f}$ の曲げ疲労曲線を用いて決定論的に解 析を行うと，その場合の疲労值 $F D$ を求めることがで きる．たとえば $P_{f}=50 \%$ の曲げ疲労曲線を用い，コン クリート舗装の路盤支持力係数，コンクリートの弾性係 数，ポアソン比を変化させた場合の $P_{R}-F D$ の関係は, Fig. 5 のように得られる.

Fig. 5 によれば，決定論的疲労解析によって得られた 疲労值 $F D$ と, シミュレーションによって得られた疲 労に関する信頼性確率 $P_{R}$ は，ほぼ直線関係になること がわかる。さらにこの関係は，決定論的な解析に用いる 疲労曲線の破壊確率 $P_{f}$ を変えることによって Fig. 6 に 示すように変化する. そこでこの $P_{R}-P_{f}-F D$ の関係か ら, 設計の際に基準となる疲労值 $F D=1.0$ における $P_{R}$ と $P_{f}$ の関係を求めると, Fig. 7 の実線 $(\mathrm{D}$ 交通) の上 うになる。すなわち，たとえば破壊確率 $P_{f}=25 \%$ の曲 げ疲労曲線を用いて設計した場合，設計寿命 20 年にお

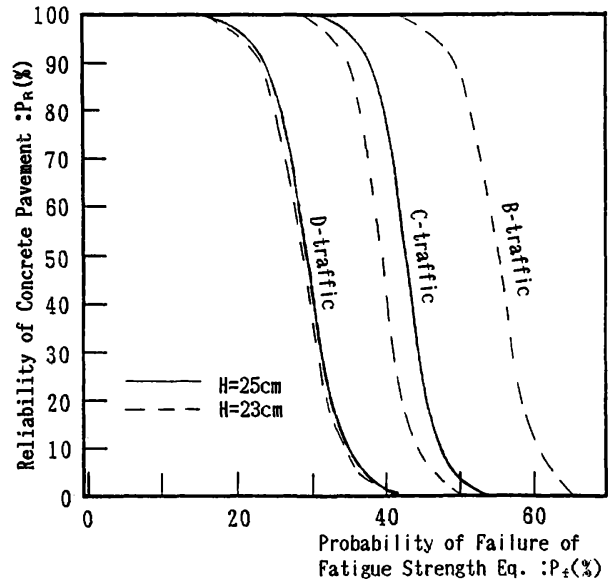

Fig. 7 Relationship between $P_{R}$ and $P_{f}$.

Table 10 Calculation Conditions for Slab Depth of $H=23 \mathrm{~cm}$.

\begin{tabular}{|c|c|c|c|c|c|c|c|c|c|c|c|}
\hline \multicolumn{4}{|c|}{ Traffic Volume Level = B } & \multicolumn{4}{|c|}{ Traffic Volume Level $=\mathrm{C}$} & \multicolumn{4}{|c|}{ Traffic Volume Level $=D$} \\
\hline \multicolumn{2}{|c|}{ Condition } & \multirow{3}{*}{$\frac{P_{\mathrm{R}}}{95.518}$} & \multirow[b]{2}{*}{ F.D. } & \multicolumn{2}{|c|}{ Condition } & \multirow[b]{2}{*}{$P_{R}$} & \multirow{3}{*}{ F.D. } & \multicolumn{2}{|c|}{ Condition } & \multirow{2}{*}{$\frac{P_{R}}{9 a^{20}}$} & \multirow{3}{*}{$\frac{\text { F.D. }}{0.164}$} \\
\hline & $\mathbf{E}$ & & & & E & & & & $\mathrm{E}$ & & \\
\hline & 300000 & & & & 300000 & & & & 300000 & & \\
\hline $\begin{array}{ll}80.25 \\
\end{array}$ & 330000 & 99.134 & 0.761 & $\begin{array}{ll}90.18 \\
\end{array}$ & 320000 & 99.608 & 0.267 & \begin{tabular}{l|l|l|}
10 & 0.18 \\
\end{tabular} & 310000 & 97.046 & 0.163 \\
\hline \begin{tabular}{l|l}
6 & 0.20 \\
\end{tabular} & 320000 & 98.408 & 0.800 & \begin{tabular}{l|l|}
10 & 0.20 \\
\end{tabular} & 330000 & & 0.346 & 100.20 & 310000 & 94.848 & 0.213 \\
\hline \begin{tabular}{l|l}
80.20 \\
\end{tabular} & 350000 & 97.661 & 0.841 & \begin{tabular}{l|l|l|}
9 & 0.20 \\
\end{tabular} & 320000 & 99.619 & 0.354 & 100.18 & 320000 & 92.70 & 0.246 \\
\hline 70.25 & 320000 & 98.981 & 0.885 & \begin{tabular}{l|l|}
8 & 0.20 \\
\end{tabular} & 310000 & 99.264 & 0.381 & 90.20 & 300000 & 92.405 & 0.215 \\
\hline 70.20 & 340000 & 97.666 & 0.969 & $\begin{array}{lll}10 & 0.18 \\
\end{array}$ & 340000 & 98.922 & 0.399 & 90.18 & 310000 & 78.002 & 0.248 \\
\hline 90.25 & 350000 & 92.955 & 1.066 & \begin{tabular}{l|l}
9 & 0.18 \\
\end{tabular} & 330000 & 99.476 & 0.406 & 80 & 300000 & 73.222 & 0.263 \\
\hline 50.20 & 310000 & 33.621 & 1.130 & \begin{tabular}{l|l|}
8 & 0.18 \\
\end{tabular} & 320000 & 68.775 & 0.436 & 100.20 & 320000 & 67.951 & 0.322 \\
\hline 80.25 & 340000 & 26.955 & 1.160 & \begin{tabular}{l|l|}
7 & 0.20 \\
\end{tabular} & 300000 & 29.268 & 0.438 & \begin{tabular}{l|l}
9 & 0.20 \\
\end{tabular} & 310000 & 64.570 & 0.328 \\
\hline 60.20 & 330000 & 15.843 & 1.217 & \begin{tabular}{|l|l|}
7 & 0.18 \\
\end{tabular} & 310000 & 29.310 & 0.500 & $\begin{array}{lll}10 & 0.18\end{array}$ & 330000 & 46.189 & 0.373 \\
\hline \begin{tabular}{l|l}
7 & 0.25 \\
\end{tabular} & 330000 & 13.877 & 1.3 & \begin{tabular}{l|l}
10 & 0.20 \\
\end{tabular} & 340000 & 69. & 0.5 & 80 & & 10.820 & 0.4 \\
\hline \begin{tabular}{l|l}
7 & 0.20 \\
\end{tabular} & 350000 & 32.141 & 1.472 & \begin{tabular}{l|l}
9 & 0.20
\end{tabular} & 330000 & 67.1 & 0.539 & 80.20 & 300000 & 3.608 & 0.34 \\
\hline \begin{tabular}{|l|l|l}
5 & 0.25 \\
\end{tabular} & 300000 & 3.548 & 1.61 & \begin{tabular}{|l|l|}
8 & 0.20 \\
\end{tabular} & 320000 & 24.098 & 0.581 & \begin{tabular}{l|l|}
7 & 0.18 \\
\end{tabular} & 300000 & 2.765 & 0.45 \\
\hline \begin{tabular}{l|l}
5 & 0.20 \\
\end{tabular} & 320000 & 1.778 & 1.723 & 90.18 & 340000 & & & & 320000 & & \\
\hline \begin{tabular}{l|l|l|}
8 & 0.25 \\
\end{tabular} & 350000 & 5.203 & 1.767 & \begin{tabular}{l|l}
6 & 0.18 \\
\end{tabular} & 300000 & 18.363 & 0.624 & \begin{tabular}{l|l}
10 & 0.18 \\
\end{tabular} & 340000 & 1.367 & 0.56 \\
\hline \begin{tabular}{|l|l|l|}
6 & 0.20 \\
\end{tabular} & 340000 & 2.877 & 1.852 & \begin{tabular}{|l|l|l|}
8 & 0.18 \\
\end{tabular} & 330000 & 20.323 & 0.663 & & 330000 & 1.317 & 0.570 \\
\hline & & & & 70.20 & 310000 & 20.343 & 0.668 & $\begin{array}{l}90 . \\
\end{array}$ & 320000 & & \begin{tabular}{|l|}
0.496 \\
\end{tabular} \\
\hline & & & & $\begin{array}{l}70.18 \\
\end{array}$ & 320000 & \begin{tabular}{|l|}
7.779 \\
\end{tabular} & & \begin{tabular}{l|l}
10 & 0.20 \\
\end{tabular} & 330000 & 0.751 & 0.48 \\
\hline & & & & \begin{tabular}{l|l}
90.20 \\
\end{tabular} & 340000 & 14.049 & 0.8 & \begin{tabular}{l|l}
8 & 0.20 \\
\end{tabular} & 310000 & 0.32 & 0.528 \\
\hline & & & & \begin{tabular}{|l|l|}
6 & 0.20 \\
\end{tabular} & 300000 & 1.046 & 0.840 & & & & \\
\hline & & & & 80.20 & & & & & & & \\
\hline
\end{tabular}


Table 11 Calculation Conditions for Slab Depth of $H=25 \mathrm{~cm}$.

\begin{tabular}{|c|c|c|c|c|c|c|c|c|}
\hline \multicolumn{5}{|c|}{ Traffic Volume Level $=C$} & \multicolumn{4}{|c|}{ Traffic Volume Level $=D$} \\
\hline \multicolumn{3}{|c|}{ Condition } & \multirow[b]{3}{*}{99.487} & \multirow[b]{2}{*}{ P.D. } & \multicolumn{2}{|c|}{ Condition } & \multirow{3}{*}{$\frac{\mathrm{P}_{\mathrm{B}}}{98.637}$} & \multirow{3}{*}{$\frac{\text { P.D. }}{0.154}$} \\
\hline & & $E$ & & & \begin{tabular}{|l|l}
$K_{75}$ & $\mu$ \\
10
\end{tabular} & \begin{tabular}{|c|}
$E$ \\
\end{tabular} & & \\
\hline & 0.25 & 320000 & & 0.375 & \begin{tabular}{l|l|l|}
10 & 0.25 \\
\end{tabular} & 350000 & & \\
\hline & 70.25 & 350000 & 99.403 & 0.380 & $\begin{array}{l}7 \\
0.25\end{array}$ & 320000 & 97.709 & 0.158 \\
\hline & 0.20 & 340000 & 99.834 & 0.430 & \begin{tabular}{l|l}
5 & 0.20
\end{tabular} & 310000 & 97.776 & 0.176 \\
\hline & 0.25 & 330000 & 88.549 & 0.567 & \begin{tabular}{l|l}
7 & 0.20
\end{tabular} & 340000 & 98.799 & 0.188 \\
\hline & 0.20 & 350000 & 34.479 & 0.647 & 60.20 & 330000 & 96.191 & 0.213 \\
\hline & 0.25 & 340000 & 21.915 & 0.857 & 90.25 & 350000 & 96.104 & 0.222 \\
\hline & & & & & \begin{tabular}{l|l}
8 & 0.25 \\
\end{tabular} & 340000 & 95.487 & 0.223 \\
\hline & & & & & \begin{tabular}{l|l}
50.25 \\
\end{tabular} & 300000 & 72.786 & 0.228 \\
\hline & & & & & $\begin{array}{l}7 \\
70.25 \\
\end{array}$ & 330000 & 60.519 & 0.237 \\
\hline & & & & & \begin{tabular}{l|l}
50.20 \\
\end{tabular} & 320000 & 61.485 & 0.265 \\
\hline & & & & & \begin{tabular}{l|l}
6 & 0.25 \\
\end{tabular} & 320000 & 61.135 & 0.271 \\
\hline & & & & & $\begin{array}{l}7 \\
0.20\end{array}$ & 350000 & 84.309 & 0.282 \\
\hline & & & & & $\begin{array}{lll}6 & 0.20\end{array}$ & 340000 & 43.873 & 0.319 \\
\hline & & & & & $\begin{array}{ll}80.25 \\
\end{array}$ & 350000 & 29.422 & 0.336 \\
\hline & & & & & 50.25 & 310000 & 27.777 & 0.344 \\
\hline & & & & & $\begin{array}{l}7 \\
0.25\end{array}$ & 340000 & 24.103 & 0.357 \\
\hline & & & & & 50.20 & 330000 & 24.119 & 0.399 \\
\hline & & & & & \begin{tabular}{l|l}
6 & 0.25 \\
\end{tabular} & 330000 & 12.323 & 0.409 \\
\hline & & & & & \begin{tabular}{l|l}
6 & 0.20 \\
\end{tabular} & 350000 & 0.479 & 0.479 \\
\hline & & & & & \begin{tabular}{l|l}
5 & 0.25 \\
\end{tabular} & 320000 & 5.870 & 0.518 \\
\hline & & & & & $\begin{array}{ll}7 & 0.25 \\
\end{array}$ & 350000 & 0.157 & 0.537 \\
\hline & & & & & 50.20 & 340000 & 1.151 & 0.599 \\
\hline
\end{tabular}

いて, 疲労に関する信頼性確率 $P_{R}$ は約 $85 \%$ である.

本研究では以上の解析を版厚 $H=23,25 \mathrm{~cm}$, および 交通量区分 $\mathrm{B}, \mathrm{C}, \mathrm{D}$ の場合について行い, さらに広範 囲の設計条件に対する $P_{R}-P_{\boldsymbol{f}}-F D$ の関係を求めた. 計 算の対象とした舗装構造条件は広範囲に選択したが, 疲 労解析では応力レベルごとの繰り返し回数が同じ場合に は同じ結果となることから, 計算を行った舖装構造条件 を整理すると Table 10, 11 に示すようになる.なお版 厚 $28 \mathrm{~cm}$ 以上の場合, 今回の解析で用いた修正設計法 によれば，設計寿命 20 年ではコンクリート版の疲労に よる破壊は生じないことから,検討の対象から除外した。

Fig. 7 において, C 交通と D 交通の場合を比較すると, 交通条件が同じ場合, $P_{f}$ 亡 $P_{R}$ の関係は, 版厚にかか わらずほぼ同じ傾向を示すといえる.すなわち疲労に関 する信頼性確率 $P_{R}$ は, コンクリート舗装の構造に依存 せず，選択した曲げ疲労曲線の破壊確率 $P_{f}$ と交通条件 によって決まることがわかる．また同図によれば，同じ 信頼性水準 $P_{R}$ を得るためには, 重交通になるほど曲げ 疲労設計曲線の破壊確率 $P_{f}$ を小さくしなければならな いことがわかる.

\section{6. 結 論}

本論文は, 舗装用コンクリートの静的曲げ強度がその 疲労破壊に与える影響に関して行った実験結果と, 著者 らによる舗装用コンクリートの曲げ疲労に関する一連の 研究の総括として, 破壊確率を考慮した疲労曲線に関す る検討結果を報告したものである.その主な結論は次の とおりである.

コンクリートの曲げ疲労に関する実験結果において, 応力レベル $S \geqq 0.80$ の領域ではコンクリートの静的曲
げ強度が異なっても, 応力レベルと曲げ疲労破壊に至る 繰り返し数の関係は同一であることが, 統計的検定に よって判明した. 一方, 応力レベル $S<0.80$ の領域では, 静的曲げ強度の増加に伴って疲労強度が増加する傾向が ある.しかしコンクリート舗装の設計においては，応力 レベル $S \geqq 0.80$ の応力状態が問題となるので, コンク リートの静的曲げ強度の相違の影響は央用上, 無視でき るといえる.

コンクリートの曲げ疲労現象のばらつきが, コンク リート版の疲労破壊に与える影響を, モンテカルロシ ミュレーションによって検討した.この結果, コンクリー トの曲げ疲労曲線の破壊確率と, コンクリートの疲労強 度のばらつきに起因する破壊に対するコンクリート舗装 の信頼性確率との関係が得られた。この関係に基づいて 選択された曲げ疲労設計曲線を用いることによって，コ ンクリートの曲げ疲労強度のばらつきにかかわるコンク リート舗装の信頼性を保証することができる.さらにこ の関係は, 検討の対象とした舗装構造条件の範囲では, 舗装の構造特性とは無関係であり, 交通条件によっての み影響されることがわかった。

\section{参 考 文 献}

1）小梁川雅・国府勝郎・福田 正：コンクリート舗装版の 曲げ疲労に関する基礎的研究, 土木学会論文集, 第 372 号/V-5, pp. 131〜137, 1986.

2）七メントコンクリート舗装要綱, 日本道路協会, 1984 .

3）レディーミクストコンクリート工場から出荷された舗装 用コンクリートの実績調查，七メント協会道路技術専門 委員会報告 R-5, 1986.

4）小梁川雅・福田 正：含水変化を受けたコンクリート供 試体の曲げ強度, 土木学会論文集, 第 354 号 $/ \mathrm{V}-2$ (ノー ト), pp. 157 160, 1985.

5）浜田純夫 - 中川健治・成岡昌夫：疲労試験における途中 打与切りデー夕の処理に関する研究, 土木学会論文報告 集, 第 189 号, pp. 99 105, 1971.

6）岩間 滋：コンクリート埔装の構造設計に関する実験的 研究 (3), 土木研究所報告第 117 号, pp. 1 124, 1964.

7) Fukuda, T., Koyanagawa, M. and Murai, S. : Condition Survey of Concrete Pavements and Its Evaluation, Proceedings of Third International Conference on Concrete Pavement Design and Rehabilitation, pp.519 523, 1985.

8）島田洋一・Montaño, J. R. · 小梁川雅：車輪通過位置に 関する研究, 土木学会東北支部技術研究発表会講演概要 集, pp. 292 293, 1987.

9) 飯島 尚-今井 博: 車両重量調查結果の解析, 道路, pp. 42 48, Jun., 1982.

10) Montaño, J.R., Koyanagawa, M. and Fukuda, T. : Evaluation of Service Life of Concrete Pavement by Monte Carlo Simulation, Proceedings of JSCE, No. $402 /$ V-10, pp. 161 167, 1989.

(1990.6.6 • 受付) 